\title{
FATAL GROUP A STREPTOCOCCAL TOXIC SHOCK-LIKE SYNDROME IN A CHILD WITH VARICELLA: REPORT OF THE FIRST WELL DOCUMENTED CASE WITH DETECTION OF THE GENETIC SEQUENCES THAT CODE FOR EXOTOXINS SPE A AND B, IN SÃO PAULO, BRAZIL
}

\author{
Jaques SZTAJNBOK(1), Marguerite LOVGREN(2), Maria Cristina C. BRANDILEONE(3), Paulo C.F.MAROTTO(1), James A. TALBOT(2) \& Antonio C. SEGURO(1)
}

\section{SUMMARY}

A previously healthy seven-year-old boy was admitted to the intensive care unit because of toxaemia associated with varicella. He rapidly developed shock and multisystem organ failure associated with the appearance of a deep-seated soft tissue infection and, despite aggressive treatment, died on hospital day 4. An M-non-typable, spe A and spe B positive Group A Streptococcus was cultured from a deep soft tissue aspirate. The criteria for defining Streptococcal toxic shock-like syndrome were fulfilled. The authors discuss the clinical and pathophysiological aspects of this disease as well as some unusual clinical findings related to this case.

KEYWORDS: Group A streptococcus; Toxic shock syndrome; Necrotizing fasciitis; Varicella; Streptococcal pyrogenic exotoxin; Clindamycin; Child.

\section{INTRODUCTION}

Since the mid 1980s, there has been a worldwide increase in the incidence of severe invasive disease caused by group A Streptococcus (GAS), mainly in North America and in Europe ${ }^{2}$. Also a syndrome similar to Staphylococcal Toxic Shock Syndrome has been described and denominated Streptococcal Toxic Shock-Like Syndrome (Strep TSLS). Despite this fact, well documented reports of this disease in Brazil are rare. We describe the first well documented case of Group A Strep TSLS in São Paulo in a seven-year-old boy with the detection of the genetic sequences that code for GAS exotoxins SPE A and B, and discuss some aspects concerning the virulence factors, pathogenesis and treatment of this potentially life threatening disease.

\section{CASE REPORT}

A previously healthy seven-year-old boy was admitted to the intensive care unit because of toxaemia and decreased level of consciousness associated with varicella. He had been well until four days earlier when fever $\left(38^{\circ} \mathrm{C}\right)$ and vomiting started. His symptoms progressively worsened over the next three days with the appearance of toxaemia and he was taken to the hospital. The physical examination on admission revealed a dehydrated, well nourished, well developed child, with weight around the $75^{\text {th }}$ percentile for age. He was tachypneic, toxaemic, confused and somnolent, with typical varicella eruptions spreading over the trunk, arms, and legs. A localized swelling with tenderness and pain was observed on the anterior left-sided thoracic wall extending to the left shoulder, without fluctuation points. His temperature was $38^{\circ}$ $\mathrm{C}$, the pulse rate was $120 \mathrm{~b} / \mathrm{m}$, the respiratory rate was $24 \mathrm{~b} / \mathrm{m}$ and blood pressure was $90 \times 60 \mathrm{mmHg}$. The peripheral pulses were all palpable but capillary filling was decreased. The remainder of the physical examination was normal. The initial laboratory studies included: $\mathrm{Na} 121 \mathrm{mEq} / \mathrm{L}, \mathrm{K} 4.4 \mathrm{mEq} / \mathrm{L}$, blood urea $96 \mathrm{mg} / \mathrm{dL}$, creatinine $1.1 \mathrm{mg} / \mathrm{dL}$, lactate dehydrogenase level $1041 \mathrm{U} / \mathrm{L}$, aspartate aminotransferase level $198 \mathrm{U} / \mathrm{L}$, alanine aminotransferase level $57 \mathrm{U} / \mathrm{L}$, prothrombin time $>120$ s $(<10 \%)$, partial thromboplastin time $43 \mathrm{~s}$, white blood cell count (WBC) of $45,100 /$ $\mathrm{mm}^{3}$ (15\% band forms, $73 \%$ segmented neutrophils, $7 \%$ lymphocytes and $7 \%$ monocytes), haemoglobin $(\mathrm{Hb})$ of $11.8 \mathrm{~g} / \mathrm{dL}$, hematocrit $(\mathrm{Ht})$ of $33 \%$, and platelet count of $95000 / \mathrm{mm}^{3}$. Arterial blood gases analysis while receiving $4 \mathrm{~L}$ of oxygen in a facial mask showed: $\mathrm{pH} 7.34, \mathrm{paCO}_{2} 22 \mathrm{mmHg}, \mathrm{paO}_{2} 138 \mathrm{mmHg}$, bicarbonate $12.0 \mathrm{mEq} / \mathrm{L}$. The remainder of blood chemistry and urinalysis were normal. A needle aspirate of the deep soft tissues from the anterior thoracic wall was performed yielding $1.0 \mathrm{ml}$ of serous fluid. Grampositive cocci in chains were observed in the Gram stain. Samples of this aspirate, blood, and urine were sent for culture and IV clindamycin and ceftriaxone were started. Over the following days, his clinical condition progressively deteriorated. He developed respiratory failure which required endotracheal intubation for mechanical ventilatory support, and shock which was unresponsive to fluid replacement and vasoactive drugs. Despite maximal support therapy, the patient's condition deteriorated further and he died on

(1) Intensive Care Unit, Instituto de Infectologia Emílio Ribas. São Paulo,Brazil.

(2) National Centre for Streptococcus, Provincial Laboratory of Public Health, Edmonton, Alberta, Canada.

(3) Bacteriology Division, Instituto Adolfo Lutz, São Paulo, Brazil

Correspondence to: Jaques Sztajnbok, M.D., Alameda Lorena 1858, Apto 31, 01424-002 São Paulo, SP, Brazil. FAX: 55-11-8531391. E- mail: jaquess@icr.hcnet.usp.br 
SZTAJNBOK, J.; LOVGREN, M.; BRANDILEONE, M.C.C.; MAROTTO, P.C.F.; TALBOT, J.A. \& SEGURO, A.C. - Fatal groupA streptococcal toxic shock-like syndrome in a child with varicella: report of the first well documented case with detection of the genetic sequences that code for exotoxins SPE A and B, in São Paulo, Brazil. Rev. Inst. Med. trop. S. Paulo, 41 (1): 63-65, 1999.

the hospital day 4. Authorization for necropsy was denied. The aspirate culture drawn at admission grew group A streptococci (Streptococcus pyogenes). The strain was lyophilized and sent to the National Centre for Streptococcus (Edmonton, Alberta, Canada) for serotyping of $M$ and $T$ proteins, opacity factor (OF) determination, and for detection of the genetic sequences that code for Streptococcal pyrogenic exotoxins A, B and C.The strain was $\mathrm{M}$ non-typable, T14, serum opacity factor negative and carried spe $A$ and spe $B$ genes.

\section{DISCUSSION}

In recent years there has been a worldwide increase of reported invasive diseases caused by GAS and of Strep TSLS. The clinical course presented by this child as well as the laboratory and culture results satisfied the criteria proposed by the Working Group on Severe Streptococcal Infections for defining Strep TSLS ${ }^{19}$ (Table 1). The severity and characteristic fulminant course of this disease are due to both host and bacterial factors ${ }^{2}$. Streptococcal TSLS is uncommon in children ${ }^{4}$, but for these patients, predisposing factors include varicella, which was present in our case, burns, malignant neoplasms and age $<2$ years ${ }^{3,9,13}$. The association between invasive GAS disease and varicella has long been known and it has been found in up to $47 \%$ of reported cases in some published series ${ }^{2}$. The rupture of the skin integrity following typical varicella lesions is believed to facilitate invasion by GAS thus providing an explanation for this association. An impaired host immune response secondary to varicella could provide an alternative explanation, but this impairment remains to be proven ${ }^{2}$. A large number of bacterial virulence factors contribute to the pathogenicity of invasive GAS.

TABLE 1

Case definition of streptococcal toxic shock

\section{A) HYPOTENSION, SHOCK}

\section{B) ISOLATION OF GAS* FROM:}

Normally sterile body site (definite)

Non-sterile body site (probable)

\section{C) TWO OR MORE OF THE FOLLOWING SYMPTOMS:}

Fever $\geq 38.5^{\circ} \mathrm{C}$

Scarlet fever rash

Vomiting and diarrhea

Liver dysfunction

Renal failure

Adult respiratory distress syndrome

Diffuse intravascular coagulation

Necrotizing fasciitis, myositis, or both

LEGEND: The criteria for defining streptococcal toxic shock-like are fulfilled when $A+B+C$ are present, with or without GAS bacteremia. (Adapted from reference 19 ).

* Group A streptococcus
M protein, a GAS surface antigen, has the ability to prevent phagocytosis of Streptococcus by human polymorphonuclear leukocytes and permits initiation of infection if $M$ type-specific antibodies are absent ${ }^{2,13}$. Epidemiological investigations during the recent resurgence of invasive GAS disease have linked the $M$ types 1,3 and $18^{2,5,12,13,15}$ to invasive and fatal infections. A recent Canadian study of 77 cases of necrotizing fasciitis reported M1 (35\%) and M3 (25\%) as the most common serotypes ${ }^{7}$, but an earlier study in the same geographic region failed to find an association between M1 and streptococcal TSLS ${ }^{4}$. Our strain was M nontypable and can be considered unusual. Group A streptococci that carry the T14 protein antigen and are opacity factor negative typically type as M14, M51 or M80; those that are opacity factor positive may belong to types M49 or M596. Curiously, our previous published report of GAS TSLS ${ }^{17}$ was also due to a M non-typable strain. The inability to classify the $\mathrm{M}$ type may reflect our limited knowledge of $\mathrm{M}$ serotypes that are common in Brazil. Both exotoxins A and B appear to mediate fever, tissue injury and toxic shock. Streptococcal pyrogenic exotoxin A is a superantigen which may play a role in streptococcal $\mathrm{TSLS}^{8}$, but the ability to produce this exotoxin is not consistent for all group A streptococci causing severe disease. Fewer than half of the isolates associated with necrotizing fasciitis in one study carried the spe $A$ gene, a characteristic that has been associated with the M1 serotype ${ }^{4,7}$. The presence of the spe $B$ gene for our isolate is not remarkable since virtually all GAS strains carry this gene ${ }^{4}$. Although not considered to act as a superantigen, SPE B plays an important role in pathogenesis, perhaps because of its equivalence to the precursor forms of streptococcal cysteine proteinase, a known GAS virulence factor ${ }^{2}$. The clinical features presented by this child, with evidence of soft tissue infection such as localized swelling, tenderness, and pain on the anterior left sided thoracic wall, strongly suggested the presence of the syndrome of necrotizing fasciitis (NF), a deep-seated infection of subcutaneous tissue usually progressing to destruction of fascia and fat ${ }^{18}$. In fact, this syndrome can be present in as much as $50 \%$ of Strep TSLS cases ${ }^{1,19}$, in which it usually presents as a diffuse swelling of an arm or leg, with rapid progression to cutaneous necrosis when bullae and a violaceous skin discoloration become apparent ${ }^{18}$. Sometimes this cutaneous evidence of NF may be absent making the differential diagnosis difficult. The treatment of NF requires both surgical and antimicrobial treatment. The best antibiotic choice to treat invasive GAS infections remains controversial. Although all the GAS strains remain sensitive to penicillin, when large inocula are present, penicillin may become less effective. This is because large inocula may reach the stationary growth phase rapidly and express decreased levels of penicillin-binding proteins (PBPs) ${ }^{14}$. In this situation, clindamycin has been shown to be preferable to penicillin. Clindamycin does not suffer the "inoculum effect", does not need to bind to PBPs, and finally its inhibition of protein synthesis may block production of $\mathrm{M}$ proteins, SPE and proteases, thus adding another theoretical advantage to its antibacterial action. Since SPEs play an important role for the pathogenesis of Strep TSLS, the use of IV immunoglobulins to neutralize circulating toxins seems reasonable. This therapy has been successfully used in other probable superantigen-mediated diseases such as Kawasaki disease and also in staphylococcal TSS. It has also been suggested that 
SZTAJNBOK, J.; LOVGREN, M.; BRANDILEONE, M.C.C.; MAROTTO, P.C.F.; TALBOT, J.A. \& SEGURO, A.C. - Fatal groupA streptococcal toxic shock-like syndrome in a child with varicella: report of the first well documented case with detection of the genetic sequences that code for exotoxins SPE A and B, in São Paulo, Brazil. Rev. Inst. Med. trop. S. Paulo, 41 (1): 63-65, 1999.

this therapy has been successful in some anecdotal reports of Strep TSLS $^{10,16}$, although randomized clinical data are lacking ${ }^{16}$. Despite all the recently accumulated knowledge regarding this subject, mortality remains high. Physicians must be aware of the possible presence of this infection when faced with any patient who presents with the clinical findings described above. Once suspected, strong efforts should be made for the identification of the agent and treatment consisting of surgery and appropriate antimicrobial treatment should be initiated. Accurate diagnosis and prompt treatment continue to be the cornerstones for a successful treatment of this potentially life threatening disease.

\section{RESUMO}

\section{Síndrome do choque tóxico por estreptococo do grupo A em uma criança com varicela: relato do primeiro caso bem documentado com a identificação dos genes codificadores da produção de SPE A e SPE B em São Paulo, Brasil.}

Criança de sete anos, previamente hígida, foi admitida na unidade de terapia intensiva por quadro de toxemia associado à varicela. Evoluiu rapidamente para choque e insuficiência de multiplos órgãos e sistemas e, apesar do tratamento intensivo, morreu no $4^{\circ}$ dia após a admissão. A cultura de secreção colhida por punção profunda de partes moles em região torácica foi positiva para Streptococcus pyogenes, proteina-M não tipável e carreador dos genes codificadores da produção de exotoxinas pirogênicas estreptocócicas A e B, preenchendo os critérios para definição de Síndrome do choque tóxico estreptocócico. Os autores discutem aspectos clínicos e fisiopatológicos desta síndrome, bem como alguns aspectos incomuns relacionados a este caso.

\section{REFERENCES}

1. BISNO, A.L. \& STEVENS, D.L. - Streptococcal infections of skin and soft tissues. New Engl. J. Med., 334: 240-245, 1996.

2. CURTIS, N. - Invasive group A streptococcal infections. Curr. Opin. infect. Dis., 9: 191-202, 1996.

3. DAVIES, H.D.; MATLOW, A.; SCRIVER, S.R. et al. - Apparent lower rates of streptococcal toxic shock syndrome and lower mortality in children with invasive Group A streptococcal infections compared with adults. Pediat. infect. Dis. J., 13: 49-56, 1994.

4. DAVIES, H.D.; McGEER, A.; SCHWARTZ, B. et al. - Invasive group A streptococcal infections in Ontario, Canada. New Engl. J. Med., 335: $547-554,1996$.

5. JOHNSON, D.R.; STEVENS, D.L. \& KAPLAN, E.L. - Epidemiologic analysis of Group A Streptococcal serotypes associated with severe systemic infections, rheumatic fever, or uncomplicated pharyngitis. J. infect. Dis., 166: 374-382, 1992.
6. JOHNSON DR \& KAPLAN, E.L - A review of the correlation of Tagglutination patterns and $\mathrm{M}$-protein typing and opacity factor production in the identification of group A streptococci. J. med. Microbiol., 38: 311 315,1993

7. KAUL, R.; McGEER, A.; LOW, D.E. et al. - Population-based surveillance for group A streptococcal necrotizing fasciitis: clinical features, prognostic indicators, and microbiologic analysis of seventy-seven cases. Amer. J. Med., 103: 18-24, 1997

8. KOTB, M. - Bacterial pyrogenic exotoxins as superantigens. Clin. Microbiol. Rev., 8: 411-426, 1995.

9. MOSES, A.E.; ZIV, A.; HARARI, M. et al. - Increased incidence and severity of Streptococcus pyogenes bacteremia in young children. Pediat. infect. Dis. J., 14: 767-770, 1995.

10. NORRBY-TEGLUND, A.; BASMA, H.; ANDERSSON, J. et al. - Varying titers of neutralizing antibodies to streptococcal superantigens in different preparations of normal polyspecific immunoglobulin G: implications for therapeutic efficacy. Clin. infect. Dis., 26: 631-638, 1998.

11. NORRBY-TEGLUND, A. \& STEVENS, D.L. - Novel therapies in streptococcal toxic shock syndrome: attenuation of virulence factor expression and modulation of the host response. Curr. Opin. infect. Dis., 11: 285-291. 1998.

12. SCHWARTZ, B.; FACKLAM, R.R. \& BREIMAN, R.F. - Changing epidemiology of group A streptococcal infection in the USA. Lancet, 336: $1167-1171,1990$.

13. STEVENS, D.L. - Invasive Group A Streptococcus infections. Clin. infect. Dis., 14: 2-13, 1992.

14. STEVENS, D.L.; GIBBONS, A.E.; BERGSTROM, R. \& WINN, V. - The Eagle Effect revisited: efficacy of clindamycin, erythromycin, and penicillin in the treatment of streptococcal myositis. J. infect. Dis., 158: 23-28, 1988

15. STEVENS, D.L.; TANNER, M.H.; WINSHIP, J. et al. - Severe group A streptococcal infections associated with a toxic shock-like syndrome and scarlet fever toxin A. New Engl. J. Med., 321: 1-7, 1989

16. STEVENS, D.L. - Rationale for the use of intravenous gamma globulin in the treatment of streptococcal toxic shock syndrome. Clin. infect. Dis., 26: $639-641,1998$

17. SZTAJNBOK, J.; MAROTTO, P.C.F.; SANTOS, D.L. et al. - Group A streptococcal meningitis and toxic shock-like syndrome in a three-monthold girl in Brazil. Infect. Dis. clin. Pract., 6: 485-487, 1997.

18. SZTAJNBOK, J.; SZTAJNBOK, S.; MAROTTO, P.C.F. \& SEGURO, A.C. Fasciíte necrotizante. Relato de caso e revisão de literatura. Rev. Hosp. Clín. Fac. Med. S. Paulo, 53: 34-38, 1998

19. THE WORKING GROUP ON SEVERE STREPTOCOCCAL INFECTIONS Defining the group A streptococcal toxic shock syndrome. Rationale and consensus definition. J. Amer. med. Ass., 269: 390-391, 1993.

Received: 28 July 1998

Accepted: 17 September 1998 
